ROCZNIKI TEOLOGICZNE

Tom LXVI, zeszyt 2 - 2019

DOI: http://dx.doi.org/10.18290/rt.2019.66.2-8

KS. MATEUSZ KANDZIA

\title{
ANTAGONIZMY JEROZOLIMSKO-SAMARYTAŃSKIE ZA CZASÓW EZDRASZA I NEHEMIASZA
}

\author{
JEWISH-SAMARITAN ANTAGONISM IN THE TIME OF EZRA AND NEHEMIAH
}

A b s t r a c t. The history of the Samaritans is strictly linked with the history of the Israelites. From the very beginning there was lack of unity between the tribes of the ancient Israel. After kings Salomon's' death his kingdom was divided into two separate states: Judah in the south and Israel in the north. In 722/21 BC the kingdom of Israel had collapsed after Assyrian invasion. Many local inhabitants were taken captivity and deported to Assyria. On their place new people were settled. The society of the former kingdom became mixed. This was the beginning of the Samaritan community.

The next important event that led to the Samaritan schism was the collapse of the Kingdom of Judah in 587/586 BC. Their inhabitants were taken captivity to Babylon. It lasted for 50 years. In 538 the Jews were permitted return. After returning to Palestine, they wanted to rebuild their ethnic and religious community concentrated around the Temple. Samaritans wanted to take part in the reconstruction of the Temple, but their request was denied. Among many gods Samaritans worshiped Yahweh, but not in the way required by Jews from Judah. After being rejected by the Jews, Samaritans started to establish their own cult centred near the mount of Gerizim.

Key words: Samaritans; Book of Ezra; Book of Nehemiah; jewish-samaritan antagonisms; the temple of Jerusalem.

W świecie ogarniętym licznymi niepokojami, wojnami, niezgodą i niesprawiedliwością, Kościół nieustannie głosi wydarzenie Jezusa Chrystusa, który - jak to wyraził Hans Urs von Balthasar - jest „objawieniem Trójjedynej Miłości Boga”. Miłość Boża pragnie objąć każdego człowieka, w każdym

Ks. mgr MATEUSZ KANDZIA - doktorant Instytutu Teologii Dogmatycznej na Wydziale Teologii Katolickiego Uniwersytetu Lubelskiego Jana Pawła II; adres do korespondencji e-mail: kandzia.mateusz@wp.pl 
czasie, a ten uniwersalizm objawił się już w momencie rozpoczęcia publicznej działalności Jezusa, podczas wydarzenia chrztu w Jordanie. Jan Chrzciciel, widząc nadchodzącego Jezusa, powiedział: „Oto Baranek Boży, który gładzi grzech świata” (J 1,29). Joseph Ratzinger zauważa, że ,,jak w niedoli egipskiego ucisku krew baranka paschalnego miała decydujące znaczenie dla wyzwolenia Izraela, tak teraz On, Syn, który stał się Sługą - Pasterz, który stał się Barankiem - ma znaczenie już nie tylko dla Izraela, lecz dla wyzwolenia „świata” - całej ludzkości. [...] Izrael nie jest tylko dla samego siebie, lecz jego wybranie jest drogą, którą Bóg chce przyjść do wszystkich"1.

Wśród ludzi, których Jezus spotykał podczas ziemskiego życia, byli Samarytanie. Stanowili oni społeczność, z którą Żydzi pozostawali w bardzo napiętych stosunkach. Jezus, idąc wbrew przyjętym postawom, nie unikał ich. Wręcz przeciwnie - spotykał się i rozmawiał z nimi, czego świadectwem jest J 4,1-42 mówiący o spotkaniu z Samarytanką. Ewangelista Jan zauważył, że uczniowie byli zdziwieni tym, że rozmawia z samarytańską kobietą (zob. J 4,27).

Artykuł przedstawia uwarunkowania i przebieg sporów jerozolimsko-samarytańskich zrelacjonowanych w Księgach Ezdrasza i Nehemiasza. Pierwsza część podejmuje genezę Samarytan. Kolejna charakteryzuje ich społeczność w okresie po niewoli babilońskiej. W trzeciej części ukazane są konkretne spory z mieszkańcami Judy, opisane w Księgach Ezdrasza i Nehemiasza. Wzajemne antagonizmy, sięgające czasów podzielonej monarchii, objawiły się szczególnie intensywnie w okresie powygnaniowym. Były one również widoczne w czasie nauczania Jezusa z Nazaretu i przejawiały się w zróżnicowanej reakcji na Jego działalność. Na ich tle rodzący się Kościół ukazał się jako „znak i narzędzie wewnętrznego zjednoczenia z Bogiem i jedności całego rodzaju ludzkiego" (KK 1), o czym świadczą Dzieje Apostolskie $(8,14)$ : „Kiedy Apostołowie w Jerozolimie dowiedzieli się, że Samaria przyjęła słowo Boże, wysłali do niej Piotra i Jana, którzy przyszli i modlili się za nich, aby mogli otrzymać Ducha Świętego".

\section{GENEZA SPOŁECZNOŚCI SAMARYTAŃSKIEJ}

Powstanie społeczności samarytańskiej bardzo ściśle łączy się z historią narodu izraelskiego i sytuacją międzynarodową. Pod wpływem wzrostu zagro-

1 J. RAtZINGER, Opera Omnia, t. VI/1: Jezus z Nazaretu. Studia o chrystologii, przeł. M. Górecka, W. Szymona, red. K. Góźdź, M. Górecka, Lublin 2015, s. 142-143. 
żenia ze strony Filistynów oraz Ammonitów doszło do zjednoczenia wszystkich Izraelitów i powstania państwa ${ }^{2}$. Początkowo jego ustrój tylko minimalnie odbiegał od tego z okresu sędziów. Dopiero z biegiem czasu nastąpiły istotne zmiany: system plemienny został załamany, a faktycznej podstawy społecznego obowiązku nie stanowiło już przymierze z Jahwe, lecz państwo ${ }^{3}$.

Kosztem upadającej demokracji plemiennej nastąpił rozrost klasy ludzi zamożnych, co powodowało ciagłe powiększanie się przepaści między ubogimi i bogatymi. Najbardziej uwidoczniło się to za rządów Salomona, który w miejsce dwunastu pokoleń, które kiedyś w razie wojny dostarczały żołnierzy, ustanowił dwanaście okręgów podatkowych (1 Krl 4,7), z których każdy miał obowiązek utrzymania przez miesiąc królewskiego dworu. Jest też pewne, że Salomon nałożył jakiś rodzaj przymusowych robót publicznych na obywateli plemion północnych ${ }^{4}$. To spowodowało coraz bardziej rosnąca niechęć do dynastii Dawidowej, czego obrazem był niedoszły bunt robotników pod wodzą Jeroboama $\left(1 \mathrm{Krl} 11,40^{5}\right)$. John Bright twierdzi, że w końcowym okresie rządów Salomona ,plemiona północne były zupełnie zrażone do domu Dawida"6. Mieszkańcy północy czuli się też dotknięci oddaniem królowi Tyru, Hiramowi, dwudziestu miast galilejskich (1 Krl 9,10-13) w zamian za materiały na budowę pałacu i świątyni w Jerozolimie. Wybuch konfliktu był tylko kwestią czasu i nastąpił od razu po śmierci Salomona, o czym świadczy $1 \mathrm{Krl}$ 12,16: „Cóż za wspólny dział mamy z Dawidem? Wszak nie mamy dziedzictwa z synem Jessego. Do swoich namiotów idź, Izraelu! Teraz, Dawidzie, pilnuj swego domu!"

Następstwa rozłamu były wielorakie. Obok pewnych korzyści, jak uwolnienie się od obciążeń fizycznych i podatkowych, rozłam przyniósł wiele trudności. Państwo nie miało ani stolicy, ani systemu administrowania, ani wojska. Wszystko to trzeba było zorganizować. Jeroboam był też świadomy, że po podziale pozostał jeszcze jeden czynnik jednoczący pokolenia północne i południowe - świątynia jerozolimska ${ }^{7}$. Dlatego jednym z najważniejszych

\footnotetext{
${ }^{2}$ Zob. W.E. Evans, An Historical Reconstruction of the Emergence of Israelite Kingship and Reign of Saul, Winona Lake 1983, s. 61-78.

3 J. BRIGHT, Historia Izraela, przeł. J. Radożycki, Warszawa 1994, s. 228.

${ }^{4}$ T. BRZEGOWY, Jeroboam I - fundator Królestwa Izraela, STV 33(1995), s. 20.

5 „Potem Salomon wszczął poszukiwania Jeroboama, aby go zabić, ale Jeroboam schronił się do Egiptu, do Szeszonka, króla egipskiego, i został w Egipcie aż do śmierci Salomona”.

${ }^{6}$ J. BRight, Historia Izraela, s. 234; Por. J.A. Soggin, Storia d'Israele, Brecia 1984, s. 291.

${ }^{7}$ Zob. M. Nотн, Storia d'Israele, Brescia 1975, s. 285.
} 
jego postanowień było ustanowienie urzędowego kapłaństwa, niezależnego od kultu jerozolimskiego i utworzenie sanktuariów ze złotymi cielcami w Dan i Betel $^{8}$. Przez te działania Jeroboam zdecydowanie zaważył na dalszych losach pokoleń północnych. Rozpoczęło się szybkie skażenie jahwizmu na terenie Izraela, które stało się fundamentem dla dalszych odstępstw ${ }^{9}$.

Wraz z następnymi władcami kryzys religijny w Królestwie Północnym tylko się pogłębiał, czego najbardziej wyraźnym obrazem było małżeństwo Achaba z Izebel. Jak podaje Mario Liverani, za czasów tego władcy synkretyzm religijny przerodził się w walkę między ludowym i narodowym Bogiem Jahwe, a bogiem obcym i dworskim - Baalem"10. I nawet kiedy udało się zniszczyć ten kult za czasów Jehu, nadal szerzyły się rodzime kulty pogańskie o charakterze synkretycznym.

Ukształtowanie się społeczności samarytańskiej nie zależało jednak tylko od wewnętrznych uwarunkowań społeczno-religijnych Izraela. Znaczący wpływ miała też sytuacja międzynarodowa. Chodzi przede wszystkim o Asyrię, choć trzeba wspomnieć także Królestwo Damaszku. Konflikt Izraela z Asyrią zapoczątkowała antyasyryjska koalicja dwunastu królów, w której pierwszorzędną rolę odgrywali Achab i król damasceński Ben-Hadad ${ }^{11}$. Stosunki pomiędzy Damaszkiem a Izraelem nie były przyjazne, jednak Achab zdawał sobie sprawę $\mathrm{z}$ tego, że państwo to stanowiło naturalną osłonę przed ewentualną inwazją Asyryjczyków, którzy coraz wyraźnej wykazywali chęć rozciągnięcia swoich wpływów na Aram, Palestynę i fenickie miasta-państwa ${ }^{12}$.

Do ostatecznego konfliktu pomiędzy Izraelem i Asyrią doprowadziła kolejna antyasyryjska koalicja, zawarta przez króla Izraelskiego Pekacha z damasceńskim królem Resinem, do której nie chciał przystąpić król judzki Achaz. Wobec tej odmowy sprzymierzeńcy najechali Państwo Południowe ${ }^{13}$. Król Achaz zwrócił się wtedy o pomoc do władcy asyryjskiego Tiglatpilesara III

\footnotetext{
${ }^{8}$ Por. 1 Krl 12,25-33. O reformie kultu za Jeroboama zob. też: J. WARZECHA, Historia dawnego Izraela, Warszawa 2005, s. 236-237; J. BRIGHT, Historia Izraela, s. 244.

${ }^{9}$ T. Brzegowy podaje: „Tak zdegenerowana wiara jahwistyczna przygotuje podatny grunt dla kolonizatorów asyryjskich, którzy stworzą na terenie byłego Królestwa Izraela synkretyczny kult niewiele mający już wspólnego z religią objawioną" (T. BRZEGOWY, Jeroboam I - fundator Królestwa Izraela, s. 38).

${ }^{10}$ M. LiVerani, Nie tylko Biblia. Historia starożytnego Izraela, Warszawa 2014, s. 135.

${ }^{11}$ G. RicciotTI, Dzieje Izraela, s. 339. Zob. także: A. PIWowAR, Historia Izraela czasów Starego Testamentu. Od patriarchów do podboju przez Rzymian, Lublin 2013, s. 139.

12 W. ChrostowsKI, „Nic nie zostato, jak tylko samo pokolenie Judy” (2 Krl 17,18b) czy naprawdę? Zagłada Samarii i Królestwa Izraela oraz jej skutki, CT 68(1998), nr 1, s. 6.

${ }^{13}$ Wydarzenie to nazywa się dzisiaj wojną syroefraimską.
} 
(2 Krl 16,7-9), który odpowiadając na tę prośbę przystąpił do rozprawienia się z koalicjantami ${ }^{14}$. W 732 roku, w wyniku tego konfliktu nastapiły powszechne zmiany. „Największymi przegranymi byli Aramejczycy z Damaszku, którzy już nigdy nie odzyskali swojej niepodległości. Ale upadek Damaszku był poniekąd zapowiedzią końca Samarii, co nastąpiło w 722 r."15. Ostateczny upadek Państwa Północnego był konsekwencja podjętych przez ostatniego władcę Izraela, Ozeasza, prób uniezależnienia się od Asyrii po śmierci Tiglatpilesara III.

Jak zaznacza Liverani, ,przy lekturze asyryjskich inskrypcji uderza fakt, że zdobycie jakiegoś obszaru niosło ze sobą zniszczenia o przerażającej skali: unicestwione miasta, spalone wsie, zagarnięte zbiory i stada, wycięte drzewa owocowe i winnice, mieszkańcy wymordowani, a ocaleli wysiedleni" ${ }^{\prime 6}$. Deportacje ludności od czasów króla Tiglatpilesara stały się jednym z głównych narzędzi imperialnej polityki Asyrii. Zrezygnowano z nadawania statusu wasali, ponieważ nie zawsze się to sprawdzało. Podbite terytoria wcielano do państwa, a ludność silnie podporządkowywano władzy centralnej ${ }^{17}$. Pierwszej takiej deportacji ludności izraelskiej dokonał Tiglatpilesar III już w 732 r. Politykę tę kontynuował Sargon II po upadku Państwa Północnego, przy czym nadał jej pewną nowość: deportacje stały się dwukierunkowe. Sargon II nie tylko przesiedlił część Izraelitów do Asyrii, ale przymusowo osadzał na terenach byłego Królestwa Izraela obcą religijnie i etnicznie ludność sprowadzoną $\mathrm{z}$ Mezopotamii ${ }^{18}$. Z tekstów Sargona II wiemy także o tym, że przesiedlił na tereny Samarii również Arabów ${ }^{19}$.

Ostatecznym celem tych wszystkich działań była pełna asymilacja polityczna i kulturowa, mająca przemienić podbite ludy w Asyryjczyków ${ }^{20}$. Prowadziła ona przede wszystkim do przyjmowania języka aramejskiego, który był drugim najbardziej rozpowszechnionym w państwie, obok języka asyryjskiego. Natomiast pod względem religijnym, asymilacja polegała na rozprzestrzenianiu się różnobarwnego synkretyzmu, bez narzucania religii asyryjskiej.

14 J. BRIEND, Damaszek i Izrael, w: A. LemaIRE (red.), Świat Biblii, Wrocław 2001, s. 187.

15 Tamże.

${ }^{16}$ M. Liverani, Nie tylko Biblia, s. 164-165.

${ }^{17}$ W. ChrostowskI, „Nic nie zostało, jak tylko samo pokolenie Judy” (2 Krl 17,18b), s. 7.

${ }^{18}$ TENŻE, Asyryjska diaspora Izraelitów w świetle Księgi Ezechiela. Wojciechowi Pikorowi $w$ odpowiedzi, ZN SBP 9(2012), s. 369.

${ }^{19}$ M. LiVerani, Nie tylko Biblia, s. 166.

20 Tamże, s. 165. 
„Ci obcokrajowcy wnieśli swoje obyczaje i wierzenia religijne i wraz z tymi, których jeszcze sprowadzono później, zmieszali się z ocalałą ludnością izraelską. Spotkamy się później z ich potomkami jako Samarytanami”"21.

\section{SYTUACJA SAMARYTAN PO NIEWOLI BABILOŃSKIEJ}

Przed rozpoczęciem próby opisu społeczności samarytańskiej w okresie po niewoli babilońskiej, należy zastanowić się najpierw nad tym, czy można już wtedy mówić o Samarytanach jako odrębnej społeczności politycznej i religijnej?

Istnieją trzy modele wyjaśniające tę kwestię. Pierwszy - za Ferdinandem Dexingerem $^{22}$ - można określić jako model żydowski. Nawiązuje on do upadku Królestwa Północnego i wspomnianego wyżej masowego przesiedlenia ludności Samarii, co ma potwierdzenie zarówno w Biblii (2 Krl 17,6. 24-41), jak i w źródłach asyryjskich. Widzi on Samarytan jako „półnawróconych pogańskich kolonistów, pochodzących z Kuta"23 (stąd też piśmiennictwo rabiniczne nazywa ich także „Kutejczykami”). Tekst 2 Krl 17 jasno ukazuje też genezę religijnego synkretyzmu Samarytan, wyliczając dokładnie pogańskie kulty, jakie przynieśli ze sobą przesiedleńcy z Mezopotamii (2 Krl 17,30-31). Również Józef Flawiusz wskazuje na ich bogaty panteon bóstw: „Do Samarii, jak się rzekło, sprowadzono Chutejczyków; [...] Każde z tych plemion, których było pięć, przyniosło ze sobą własnego boga. Ponieważ oddawali tym bogom cześć według obyczaju swej krainy, srogo rozgniewał się na nich Bóg najwyższy i zesłał zarazę, która ich niszczyła. [...] Nie znajdując żadnego leku na swą niedolę, nagle dowiedzieli się z wyroczni, że powinni czcić najwyższego Boga, bo tylko to może ich ocalić. Wyprawili tedy posłów do króla asyryjskiego z prośbą, by przysłał im kapłanów spośród jeńców pojmanych po wojnie z Izraelitami. Król spełnił tę prośbę, a gdy kapłani pouczyli ich o prawach i o świętej służbie przy tym Bogu, Chutejczycy poczęli czcić Go bardzo gorliwie i od razu opuściła ich zaraza. Te same obrzędy przechowują się jeszcze teraz wśród ludzi zwanych po hebrajsku Chutejczykami, a po grecku Samarytanami"24. Według modelu żydowskiego repatrianci, którzy wracali z niewoli do ojczystej Ziemi, spotkali się z Samarytanami jako od-

\footnotetext{
${ }^{21}$ J. BRIGHT, Historia Izraela, s. 284.

${ }^{22}$ Zob. F. DEXINGER, Samarytanie w nauce i historii, AC 30-31(1998-1999), s. 437.

23 Tamże.

${ }^{24}$ J. Flawiusz, Dawne dzieje Izraela, IX ,14.3, przeł. E. Dąbrowski (red.), Poznań-Warszawa-Lublin 1962.
} 
dzielną religijnie grupa o synkretycznym kulcie. W takim spojrzeniu jest trochę racji, jednak - jak podaje Waldemar Chrostowski - obraz ten „stanowiąc owoc teologii deuteronomistycznej, nie wytrzymuje krytyki historycznej. Odzwierciedla nie tyle faktyczny stan rzeczy, co niechętne spojrzenie na całą przeszłość Państwa Północnego, podjęte z perspektywy judzkiej i dokonane w kontekście późniejszych polemik antysamarytańskich" ${ }^{25}$.

Oprócz modelu tradycyjnie żydowskiego istnieje także inny - samarytański. Opisuje on spojrzenie samych Samarytan na własne początki i przesuwa je na czasy wcześniejsze od upadku Królestw Izraela, do okresu sprzed panowania Króla Dawida. Odwołują się oni do 43 rozdziału samarytańskiej Księgi Jozuego: kapłan Heli opuścił świątynię na Garizim i ustanowił nowe, schizmatyckie sanktuarium w Szilo (por. $1 \mathrm{Sm} \mathrm{1,9).} \mathrm{Przodkowie} \mathrm{Samarytan} \mathrm{zacho-}$ wali jednak miejsce kultu na Garizim i tym samym stali się prawdziwym Izraelem. Stąd też miała się wziąć ich nazwa - Samarytanie - od czasownika szamar - „strzec”. Określali siebie jako szamerim - przestrzegający Prawa.

Dexinger wskazuje na jeszcze jeden model genezy Samarytan - historycznokrytyczny. Według niego doszukiwanie się samarytańskich korzeni w 2 Krl 17, 24-41 oparte jest na błędnej i tendencyjnej interpretacji, która zupełnie pomija genezę tego tekstu. Wcześniejsze przekazy tego źródła pozwalają jasno stwierdzić, że pomimo wszelkich przemian społeczno-politycznych związanych z upadkiem Królestwa Izraela, na północy ciągle istniała elita autochtonicznych wyznawców Jahwe ${ }^{26}$.

Tezę tę potwierdza Giuseppe Ricciotti, który zauważa, że mieszkańcy dawnego Królestwa Izraela przez 140 lat, a więc od chwili upadku Monarchii Północnej do upadku Judy, regularnie uczestniczyli w życiu religijnym przy Świątyni w Jerozolimie ${ }^{27}$. Wspomnieć należy przede wszystkim działalność króla Ezechiasza, który rozpoczął wśród niedobitków upadłego Państwa Północnego ,akcję prawdziwie narodową, przez wezwanie ich [...] do dawnego ośrodka jahwistycznego całego narodu" ${ }^{28}$. Dopiero z chwilą upadku Jerozolimy i zniszczenia świątyni Pańskiej, kiedy zabrakło ośrodka duchowej i religijnej formacji, mieszkańcom północy wyznającym jahwizm, jerozolimską świątynię zaczęły zastępować ośrodki lokalne, tworzone właśnie przez potomków przesiedlonych ludów. W ten sposób nasilały się praktyki synkretyczne

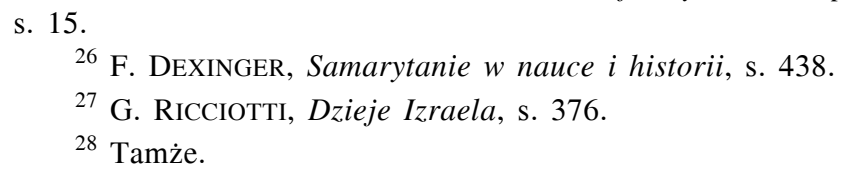


i kontakty z bóstwami ludów, które napłynęły na teren dawnego Izraela ${ }^{29}$. I właśnie do tych mieszkających na północy Izraelitów, autor natchniony kieruje tekst $2 \mathrm{Krl}$ 17,34b-41, w którym nawołuje do porzucenia synkretycznych praktyk, do czyszczenia Tory z wszelkich pogańskich interpretacji i naleciałości oraz odkrycia w dźwigającej się ze zgliszcz Jerozolimie jedynego centrum religijnego wszystkich Izraelitów.

W okresie bezpośrednio po niewoli babilońskiej nie mamy więc jeszcze do czynienia z Samarytanami, jako judaistyczną schizmą ${ }^{30}$. Julian Warzecha podaje, że ludność ta uważała się za wyznawców Jahwe, jednak ów fakt wiary należy odnosić przede wszystkim do warstwy rządzącej. Gdy spojrzeć na ogół ludności samarytańskiej, nie był to czysty jahwizm ${ }^{31}$. Dexinger, charakteryzując strukturę ludnościową prowincji Samarii po niewoli, dokonuje jasnego rozróżnienia: z jednej strony są to Samarytanie - wyznawcy kultów pogańskich, którzy po części byli też wyznawcami Jahwe, z drugiej zaś strony - autochtoniczni wyznawcy Jahwe ${ }^{32}$, których Warzecha określa wprost „Żydami samarytańskimi”,33. Pewnym jest jednak to, że nie mamy wtedy jeszcze do czynienia $\mathrm{z}$ odrębną religijnie grupą.

Kiedy Żydzi wracali z niewoli babilońskiej spotkali Samarytan jako społeczność o charakterze politycznym ${ }^{34}$. Samaria razem z Judą stanowiły dwie perskie prowincje Palestyny, pomiędzy którymi stopniowo wzrastała rywalizacja. Prowincja Samarii znajdowała się w warunkach o wiele korzystniejszych niż Juda: miała bardziej urodzajną ziemię i dobre położenie na trasie dróg handlowych. Juda oprócz gorszych warunków ekonomicznych borykała się także z faktem, że tylko repatrianci kierowali się żywą wiarą i tradycją. Religijność rodzimych mieszkańców nie była jahwizmem w czystej postaci. Dlatego z czasem prowincja Judy podjęła działania mające na celu odbudowanie instytucji stanowiących o jej ekskluzywnej tożsamości, mając na względzie przede wszystkim instytucje religijne, przy równoczesnym zachowaniu

${ }^{29}$ Zob. T. TUŁODZIECKI, Izrael i Juda: jeden naród czy dwaj rywale wobec Bożego wybrania, VV 10(2006), s. 84

${ }^{30}$ J. WARZECHA, Historia dawnego Izraela, s. 416-417.

31 Tamże, s. 422.

${ }^{32}$ F. DEXINGER, Samarytanie $w$ nauce $i$ historii, s. 438.

${ }^{33}$ J. WARZECHA, Samarytanie - perspektywa polityczna i religijna, w: W. CHROSTOWSKI, Stowo Twoje jest Prawda., Ksiega Pamiatkowa dla Ks. Prof. Stanistawa Mędali CM w 65 rocznice urodzin, Warszawa 2000, s. 341.

34 TENŻE, Historia dawnego Izraela, s. 416. 
minimum organizacji społeczno-politycznej ${ }^{35}$. „W miarę jak nadzieja ustępowała rozczarowaniu, synkretyzm niewątpliwie przybierał na sile. Przywódcy duchowi [Judy - uzupełnienie M.K.] dochodzili do przekonania że separacja w samej wspólnocie stała się koniecznością. [...] Wspólnota rozpaczliwie potrzebowała ośrodka, wokół którego skupiałaby się wiara. [...] W rzeczy samej, nie mogło być dla niej „nowej ery”, ani nawet przyszłości, jeżeli nie będzie gotowa podjąć konkretnego [...] działania, to znaczy - budowy świątyni”36. To właśnie ta postępująca izolacja stała się powodem tego, że mieszkańcy Samarii, pomimo początkowej chęci zbliżenia się do repatriantów, musieli z czasem robić wszystko, by nie utracić wpływów w coraz silniejszej prowincji judzkiej ${ }^{37}$.

Separatystyczne dążenia Judy zapoczątkowały proces, który w końcu doprowadził do tak zwanej „schizmy samarytańskiej”. Mieszkańcy Samarii z biegiem czasu zaczynali stanowić społeczność odrębną także religijnie, a nazwa „Samarytanie" odnosiła się już nie tylko do potomków przesiedlonych pogańskich ludów, ale również do samarytańskich Żydów. W wyniku tych przemian Samarytanie coraz bardziej czuli się też strażnikami czystej religii ${ }^{38}$, prawowitymi spadkobiercami Mojżesza oraz potomkami Lewiego, Manassesa i Efraima, a więc prawdziwymi Hebrajczykami i prawdziwymi Izraelitami, lecz nigdy nie uważali się za Żydów (Judejczyków).

\section{JUDEJCZYCY I SAMARYTANIE \\ W KONTEKŚCIE ODNOWY ŻYCIA RELIGIJNEGO W JEROZOLIMIE}

Po powrocie z niewoli babilońskiej pojawiły się między Judejczykami a Samarytanami konflikty dotyczące odbudowy świątyni jerozolimskiej, naprawy zniszczonych murów Jerozolimy oraz kwestii małżeństw mieszanych. Wśród antagonizmów samarytańsko-jerozolimskich, Kronikarz podaje najpierw odbudowę świątyni w Jerozolimie. Stała się ona możliwa dzięki dekretowi króla perskiego Cyrusa z 539 r. przed $\mathrm{Chr}^{39}$. Został on przekazany w dwóch formach: aramejskiej (Ezd 6,3-5) i hebrajskiej (Ezd 1,2-4). Osobną kwestią

\footnotetext{
35 TENŻE, Poczatek odbudowy, s. 346-347.

36 J. BRIGHT, Historia Izraela, s. 381.

37 T. TUŁODZIECKI, Izrael i Juda, s. 87.

${ }^{38}$ B. GóRKA, Jezus wobec judaizmu i samarytanizmu w J 4,1-30.39-42, SBO 1(2009), s. 216.

${ }^{39}$ A. Piwowar podaje, że dekret Cyrusa został wydany w 539 lub 538 roku przed Chr zob. A. PIWowar, Historia Izraela czasów Starego Testamentu, s. 362.
} 
godną podjęcia jest pytanie o wiarygodność obu tych dokumentów ${ }^{40}$. Zdania uczonych są w tej kwestii podzielone, jednak większość z nich przyjmuje stanowisko pośrednie, które nie broni każdego słowa tych dokumentów, ale ich istotną treść ${ }^{41}$, a mianowicie: wyraźną zgodę Cyrusa na budowę nowej świątyni w Jerozolimie.

Z całą pewnością dla Żydów, wracających do Judy, było to najważniejsze zadanie, nie pozbawione jednak trudności. Pierwsza grupa repatriantów, którą przyprowadził Szeszbassar, nie była liczna. Żydzi, co prawda, byli gotowi wspomóc dzieło odbudowy świątyni, ale tylko materialnie, z oddali. Nie chcieli ryzykować skomplikowanej wyprawy ${ }^{42}$. „Bądź co bądź Palestyna była dalekim krajem, który tylko najstarsi ludzie mogli pamiętać, a droga do niej trudna i niebezpieczna; przyszłość tego przedsięwzięcia w najlepszym razie była niepewna. [...] Jest rzeczą prawdopodobną, że tylko nieliczni spośród najśmielszych i najbardziej sprawie oddanych ludzi skłonni byli towarzyszyć Szeszbassarowi"

Szeszbassar - jak się wydaje - natychmiast przystąpił do pracy nad budową świątyni (Ezd 5,14-16) ${ }^{44}$. Jednak, jak informuje dalszy tekst, prace te $\mathrm{z}$ nieznanych przyczyn zostały jednak przerwane (Ezd 5,16b). Z pewnością dalszą odbudowę uniemożliwił kryzys gospodarczy, spowodowany szarańczą i suszą (Ag 1,9-11; 2,15-17) ${ }^{45}$. Bardzo szybko skończyły się pieniądze przywiezione z Babilonii, nie udało się też stworzyć bezpiecznego i sprzyjającego środowiska dla tej inicjatywy. „Ledwo rozpoczęta praca nad świątynią ustała. Ludzie pochłonięci walką o byt nie mieli już ani środków, ani energii, aby ją kontynuować" 46 .

Od samego początku odbudowie nie sprzyjały też napięte stosunki z Samarytanami. Jak zostało to zaznaczone wyżej, oni również czuli się wyznawcami Boga Jahwe, który był przecież „lokalnym bóstwem” Palestyny. Poczuli się zatem zobowiązani do przyjścia $\mathrm{z}$ pomocą w odbudowie świątyni Jahwe.

${ }^{40}$ Zob. J. WARZECHA, Historia dawnego Izraela, s. 361-363.

${ }^{41}$ Tamże, s. 362.

42 J. WARZECHA, Poczatek odbudowy, s. 351.

43 J. BRIGHT, Historia Izraela, s. 375.

${ }^{44}$ Kronikarz przypisuje położenie fundamentów Zorobabelowi. Te biblijne dane przyjmuje J. Warzecha, z zastrzeżeniem, że nie można dokładnie udowodnić, że oprócz przekazania naczyń świątynnych ów Szeszbassar kierował także budową fundamentów. Zob. J. WARZECHA, Poczatek odbudowy, s. 351; J. BRIGHT, Historia Izraela, s. 375.

45 J. WARZECHA, Poczatek odbudowy, s. 352.

46 J. BRIGHT, Historia Izraela, s. 378. 
Przedłożyli formalną propozycję Zorobabelowi i kapłanowi Jozuemu. Przyjęcie tej pomocy zburzyłoby jednak całą reformę religijną i moralną odbudowującego się narodu, dlatego Żydzi odmówili (Ezd 4,1-4).

Ze strony Samarytan sprawa rozgrywała się oczywiście o coś innego niż czystość kultu i religii. Jak zostało to już wyżej zasygnalizowane, Samaria i Juda jako dwie perskie prowincje zaczynały powoli ze sobą rywalizować. W Samarii zawsze roszczono sobie pretensje do zwierzchnictwa, czy przynajmniej pewnej kontroli nad Judą. Dlatego wszelkie próby lepszego zorganizowania się i odbudowy świątyni były rozumiane jako wyraz buntu przeciw Imperium Perskiemu. W tym kontekście skutki odmowy Żydów na propozycję Samarytan były całkowicie zrozumiałe. O ile wcześniej Samarytanie wykazywali jakieś zainteresowanie, a nawet sympatię wobec repatriantów, teraz urażeni żydowskim ekskluzywizmem stworzyli antyżydowski sojusz składający się także z innych cudzoziemców osiadłych w Palestynie, a nawet Żydów niezadowolonych z obecności repatriantów. „Był to rodzaj jednolitego frontu, jaki wytworzył się przeciwko budowniczym, zamykając ich coraz bardziej w kręgu wrogości, nienawiści i bojkotu" ${ }^{47}$. Istnienie takiej nieformalnej antyżydowskiej koalicji potwierdza Flawiusz: „Chutejczyków oburzyły te słowa. Zaraz też podmówili plemiona mieszkające w Syrii, by zażądały od satrapów [...] powstrzymania prac przy świątyni; niech wszelkimi sposobami starają się przeszkadzać Judejczykom, którzy krzątają się przy tej budowie" ${ }^{48}$. Aby uniemożliwić podjęte prace Samarytanie nie powstrzymali się też od interwencji u władzy centralnej, o czym świadczy Ezd 5,8-10.17.

Trzeba także zauważyć fakt, że przy odbudowie przybytku w Jerozolimie wraz z Judejczykami pracowali Sydończycy i Tyryjczycy, którzy - jak informuje Księga Ezdrasza - używali drzewa cedrowego sprowadzonego z Libanu (por. Ezd 3,7). Jeśli więc Tyryjczycy i Sydończycy mogli wspierać budowę, a pomoc oferowana przez Samarytan została odrzucona, był to kolejny czynnik wzmagający wzajemną wrogość.

Świątynia została wreszcie ukończona i poświęcona w 515 r. przed Chrystusem $^{49}$. Zupełnie zrozumiała jest radość, jaka budziła się w sercach Żydów na widok nowej świątyni. I chociaż daleko jej było do okazałej świą-

\footnotetext{
${ }^{47}$ G. Ricciotti, Dzieje Izraela, s. 504.

${ }^{48}$ J. FlawIUSz, Dawne dzieje Izraela, XI, 4.4.

49 Dokładna chronologia - zob. M.S. WróBEL, Księga Ezdrasza. Księga Nehemiasza. Wstęp - przektad z oryginatu - komentarz - ekskursy, Tarnów 1993, s. 102-104.
} 
tyni Salomona, ta nowa, zbudowana przez Zorobabela, miała jedną przewagę: otóż nie raziła ona ubogiej ludności swoim przepychem i bogactwem ${ }^{50}$.

Odbudowana świątynia wraz ze wznowionym w niej kultem działała integrująco w łonie tej społeczności w latach następujących po 515 roku $^{51}$, choć równocześnie należy podkreślić, że wielu ludzi pochodzenia izraelskiego w Samarii i gdzie indziej nie okazywało względem niej wierności ${ }^{52}$. Judejczycy przekonali się więc, że nie nastąpi odtworzenie narodu żydowskiego na dawną modłę, nawet w jakiejś zmienionej postaci. Oczywistym stawał się fakt, że przyszłość narodu musi kształtować się w innym kierunku ${ }^{53}$.

Niejasny pozostaje okres, który nastąpił po inauguracji świątyni. Andrzej Piwowar podaje, że po Zorobabelu prawdopodobnie nie było już żadnego żydowskiego namiestnika Judy, ponieważ administracyjnie podlegała ona nadal Samarii ${ }^{54}$. Dodatkowo Judejczycy narażeni byli na napady i grabieże, przed którymi nie mogli się bronić, ponieważ nie mieli żadnej wojskowej ochrony ${ }^{55}$. Takim zagrożeniem byli wtedy dla nich przede wszystkim Edomici, którzy pod naciskiem Arabów zmuszeni byli opuścić swoje rodzime ziemie i zaczęli zajmować południową część Palestyny aż do obszaru na północ od Hebronu. „Żydzi z pewnością nie kochali Edomitów, których poprzedniej wiarołomności nie mogli zapomnieć i których obecność na ojcowskiej ziemi budziła w nich uczucie gniewu. [...] Edomici i Arabowie bez wątpienia tak samo odwzajemniali się nienawiścią i takimi utrudnieniami, na jakie mogli się zdobyć" 56 . Z tego też powodu Judejczycy postanowili odbudować mury Jerozolimy.

Dzieła tego podjął się Nehemiasz, syn Chakaliasza, podczaszy na dworze perskim, który pozyskał względy króla Artakserksesa i objął urząd gubernatora Judy wraz z uprawnieniami do odbudowy murów Jerozolimy. Okazał się on energicznym i zdolnym człowiekiem, zatroskanym o sprawy swojego narodu. W obawie o to, aby plany prac nie zostały pokrzyżowane, Nehemiasz od razu przystąpił do działania. Nie da się dokładnie ustalić czasu podjęcia prac, z pewnością można określić, że było to przed 445 r. przed Chrystusem. Robotnicy zostali zwerbowani z całej Judy. Mur został podzielony na odcinki

\footnotetext{
50 J. WARZECHA, Poczatek odbudowy, s. 352.

51 Tamże, s. 355.

52 J. BRIGHT, Historia Izraela, s. 385.

53 Tamże, s. 387.

54 A. Piwowar, Historia Izraela czasów Starego Testamentu, s. 194.

55 Tamże, s. 194-195.

56 J. BRIGHT, Historia Izraela, s. 392.
} 
i za każdy z tych odcinków odpowiadała jakaś jedna grupa budowniczych ${ }^{57}$. Świadczy o tym fragment Ne 3,1-32, w którym począwszy od rodziny arcykapłańskiej, po kolei wymienione są poszczególne rody i osoby, biorące udział w odbudowie poszczególnych kawałków muru ${ }^{58}$. Tak zorganizowana praca trwała 50 dni. Z pewnością jednak była to tylko jakaś namiastka muru - „coś w rodzaju muru". Flawiusz podaje, że faktyczne ukończenie tego przedsięwzięcia zajęło o wiele dłużej ${ }^{59}$. Faktem jest jednak to, że Nehemiasz dokonał tego pomimo niewiarygodnych trudności. Bo chociaż wyposażony był w pełnię władzy przez królewski reskrypt i mianowanie na namiestnika, to miał on potężnych wrogów, którzy nie marnowali okazji, aby przeszkadzać. Głównymi wrogami byli oczywiście Samarytanie, których ,zamiarem było utrzymanie Judy w stanie permanentnej bezbronności" ${ }^{\prime 60}$. Warzecha podaje, że wśród wrogów Nehemiasza znaleźli się także Żydzi, zamieszkujący zarówno Judę, jak i Samarię (por. Ezd 4,4). Pewne jest to, że spory z Nehemiaszem miały charakter przede wszystkim polityczny, ponieważ działania nowego namiestnika Judy wyraźnie ujawniały separatystyczny ich charakter, podobnie jak potępienie przez niego małżeństw mieszanych, co zostanie jeszcze rozwinięte ${ }^{61}$. To wszystko było bardzo poniżające dla Samarytan. Dodatkowym czynnikiem wzmagającym ich wrogość był fakt, że Nehemiasz uznał religię Samarytan za nie do przyjęcia, a ich samych postrzegał jako pogan ${ }^{62}$.

Im bardziej postępowały prace przy budowie murów Jerozolimy, tym bardziej wzrastała wrogość Samarytan. Potwierdza to tekst biblijny (Ne 6,14), jak też świadectwo J. Flawiusza: „Skoro Ammonici, Moabici, Samarytanie i wszyscy mieszkańcy Syrii dowiedzieli się o budowaniu murów, było im to bardzo nie po myśli i wynajdywali wciąż nowe sposoby, by udaremnić zamiary Judejczyków. Wielu ich zabili, a nawet starali się zgładzić samego Nehemiasza, nająwszy w tym celu jakichś cudzoziemców. Usiłowali rozniecać wśród Judejczyków trwogę i zamęt, rozsiewali pogłoski, że wiele narodów gotuje się do napaści na nich, co Judejczyków tak przeraziło, że bliscy byli zaprzestania pracy. Nehemiasza jednak nic nie mogło odstraszyć od wytrwałych starań" $" 63$.

\footnotetext{
57 A. Piwowar, Historia Izraela czasów Starego Testamentu, s. 200.

${ }^{58}$ M.S. WróBel, Księga Ezdrasza. Księga Nehemiasza, s. 156.

${ }^{59}$ J. FlawIUsz, Dawne dzieje Izraela, XI, 5.8.

${ }^{60}$ J. BRIGHT, Historia Izraela, s. 392.

${ }^{61}$ J. WARZECHA, Samarytanie - perspektywa polityczna i religijna, s. 341.

62 J. BRIGHT, Historia Izraela, s. 396.

${ }^{63}$ J. FlawIUsz, Dawne dzieje Izraela, XI, 5.8.
} 
Nehemiasz nie dał się jednak ani zastraszyć, ani skompromitować. „Okazał się wyższy moralnie od swoich wrogów. Dzięki odwadze i zaradności przezwyciężył wszystkie przeszkody i zniechęcenia swoich zwolenników"64. Zdając sobie sprawę $\mathrm{z}$ tego, że ukończone mury nie zdołają ochronić miasta, jeśli nie będzie w nim ludzi gotowych stawić czoła wrogom. Dlatego widząc, że liczba ludności Jerozolimy jest bardzo mała, postanowił ją obsadzić nowymi mieszkańcami ( $\mathrm{Ne} \mathrm{74;} \mathrm{11,1-2).}$

Samarytanie widząc, że w obliczu judzkich reform religijnych ich położenie jest coraz gorsze, zaczęli podejmować próby zawierania małżeństw mieszanych. Był to dla nich chyba już ostatni możliwy sposób, żeby mieć jakieś wpływy na życie religijne w Judei. Jednak i w tej kwestii regulacje poczynione przez Nehemiasza były bardzo zdeterminowane, o czym świadczy Ne 13,23-29. Nehemiasz był świadomy, że trzeba „oczyścić lud z cudzoziemców" (por. Ne 13,30). Wielki ból sprawiało mu to, że potomstwo pochodzące z tych mieszanych związków traciło swoją żydowską tożsamość. Wyrazem tego u wielu $\mathrm{z}$ nich była nieznajomość języka hebrajskiego. Osłabiała ona integrację ciągle odbudowującej się wspólnoty, dlatego reakcja Nehemiasza była tak bardzo stanowcza: zabronił Żydom wydawać swoje córki mężczyznom z obcych narodów, a także żenić się z cudzoziemkami. Dla wzmocnienia swojego zakazu, przywołał nawet postać Salomona, który popadł w grzech przez podobne postępowanie. Postawa Nehemiasza bardzo wyraźnie wskazuje na to, jak Żydzi postrzegali samych siebie i jakie było ich nastawienie do wszystkiego, co obce.

Działania, które podjął Nehemiasz, „doprowadziły w krótkim czasie do wykształcenia się niezależnej od wpływów Samarii, silnej prowincji judzkiej. Zdaniem Chrostowskiego, tak zwana „schizma samarytańska”, mająca swe miejsce pod koniec VI wieku przed Chr., definitywnie dokonała się właśnie za czasów Ezdrasza i Nehemiasza, ponieważ Judejczycy, którzy po powrocie z wygnania uważali się za ,prawdziwy Izrael” doprowadzili do eliminacji i izolacji Samarytan ${ }^{65}$. Inaczej twierdzi Tomasz Tułodziecki: „Ukazane dotychczas problemy religijne czy polityczne na pewno wpłynęły na ostateczny rozłam między Żydami i Samarytanami, ale ich rola wydaje się tylko pośrednia. Ostateczne przyczyny konfliktu między tymi narodami, u którego podstaw leżało przede wszystkim zaznaczenie swojej władzy i rozciągnięcie

\footnotetext{
64 J. BRIGHT, Historia Izraela, s. 397.

${ }^{65}$ W. Chrostowski, „Nic nie zostało, jak tylko samo pokolenie Judy” (2 Krl 17,18b),
} s. 19. 
kontroli nad życiem religijnym, społecznym i politycznym tak w jednej, jak i drugiej prowincji mają inne źródło"66. Na pewno do bardzo poważnych zadrażnień doszło w czasie wojen machabejskich. Przedsięwzięciem, które ostatecznie spowodowało trwały konflikt, był najazd Jana Hirkana na Samarię i odbudowa państwa żydowskiego za panowania dynastii Hasmoneuszy ${ }^{67}$. Niezależnie od wskazanych rozważań pewne jest, że podział pomiędzy tymi dwoma narodami coraz bardziej stawał się faktem, czego widocznym znakiem miała stać się wkrótce odrębna świątynia na górze Garizim.

Podjęta refleksja na temat antagonizmów opisanych w Księgach Ezdrasza i Nehemiasza przybliża historię Samarytan, genezę ich religii i zwyczajów, a także źródła ich konfliktów z Żydami. Dla chrześcijan zagadnienia te są szczególnie interesujące, ponieważ pozwalają lepiej zrozumieć teksty nowotestamentalne wskazujące pośrednio lub bezpośrednio na uniwersalizm zbawczej misji Chrystusa: Przypowieść o Miłosiernym Samarytaninie (Łk 10,3637), historię o Samarytaninie, który jako jedyny okazał swoją wdzięczność po oczyszczeniu z trądu (Łk 17,11-19), spotkanie Jezusa z Samarytanką (J 4,1-42).

Zagadnienia te rzucają też światło na wszelkie konflikty rodzące się pomiędzy ludźmi, również we współczesnym świecie. Często są one wynikiem zamknięcia się na drugiego, tłumaczonego jego odmiennością, złym pochodzeniem i obcym światopoglądem, choć w rzeczywistości odległość między zwaśnionymi stronami - tak jak w przypadku Żydów i Samarytan - genealogicznie wcale nie musi być duża. Rzetelne poznanie swojego pochodzenia i historii, ale też historii tych, którzy żyją tuż obok, może pomóc w budowaniu pokoju i ładu społecznego, opartego na wzajemnym szacunku i dostrzeganiu w nich tego, co dobre i wartościowe. „Niewzruszona wola poszanowania wszystkich ludzi i narodów oraz ich godności, jak również wytrwałe praktykowanie braterstwa są absolutnie niezbędne do budowania pokoju" (KDK 78). Najważniejszą motywacją do takiej postawy jest prawda, że Jezus jest Barankiem Bożym za grzechy całego świata (por. J 1,29). „Ten bowiem Wcielony

${ }^{66}$ T. TUŁodZIECKI, „Schizma Samarytan” - spór o władze nad Juda i Jerozolima, VV 14(2008), s. 54.

${ }^{67}$ Zob. tamże, s. 54-55. 
Syn Boży, Książe pokoju, przez swój krzyż pojednał wszystkich ludzi z Bogiem i przywracając jedność wszystkich w jednym ludzie i jednym Ciele, w swoim własnym ciele zadał śmierć wrogości, a wyniesiony do chwały przez zmartwychwstanie wlał Ducha miłości w serca ludzkie" (KDK 78).

\section{BIBLIOGRAFIA}

BRIEND J., Damaszek i Izrael, w: A. LEMAIRE (red.), Świat Biblii, Wrocław 2001, s. 181-187. BRIGHT J., Historia Izraela, przeł. J. Radożycki, Warszawa 1994.

BRzEgOwy T., Jeroboam I - fundator Królestwa Izraela, „Studia Theologica Varsaviensia” 33(1995), s. 17-41.

Chrostowski W., Asyryjska diaspora Izraelitów w świetle Księgi Ezechiela. Wojciechowi Pikorowi w odpowiedzi, „Zeszyty Naukowe Stowarzyszenia Biblistów Polskich” 9(2012), s. 335-384.

Chrostowski W., „Nic nie zostało, jak tylko samo pokolenie Judy” (2 Krl 17,18b) - czy naprawdę? Zagłada Samarii i Królestwa Izraela oraz jej skutki, „Collectanea Theologica” 68(1998), s. 5-22.

DeXINGER F., Samarytanie w nauce i historii, „Analecta Cracoviensia” 30-31(1998-1999), s. $435-451$.

Evans W.E, An Historical Reconstruction of the Emergence of Israelite Kingship and Reign of Saul, Winona Lake 1983.

FLAwIUSz J., Dawne dzieje Izraela, IX,14.3, przeł. E. Dąbrowski, Poznań-Warszawa-Lublin 1962.

GACEK S., Księga Jozuego. Wstęp - przekład z oryginału - komentarz - ekskursy, Tarnów 1993.

GóRKA B., Jezus wobec judaizmu i samarytanizmu w J 4,1-30.39-42, „Scripta Biblica et Orientalia" 1(2009), s. 215-220.

Herrmann S., Storia di Israele. I tempi dell'Antico Testamento, Brescia 2004.

LiVERANi M., Nie tylko Biblia. Historia starożytnego Izraela, Warszawa 2014.

Noth M., Storia d'Israele, Brescia 1975.

PIwowar A., Historia Izraela czasów Starego Testamentu. Od patriarchów do podboju przez Rzymian, Lublin 2013.

RAtzinger J., Opera Omnia, t. VI/1: Jezus z Nazaretu. Studia o chrystologii, przeł. M. Górecka, W. Szymona, red. K. Góźdź, M. Górecka, Lublin 2015, s. 142-143.

RosıK M., Jezus a judaizm w świetle Ewangelii według św. Marka, Warszawa 2004.

SogGin J.A., Storia d'Israele, Brecia 1984.

TUŁODZIECKI T., Izrael i Juda: jeden naród czy dwaj rywale wobec Bożego wybrania, „Verbum Vitae" 10(2006), s. 71-91.

TUŁoDZIECKI T., „Schizma Samarytan” - spór o władzę nad Judą i Jerozolimą, „Verbum Vitae” 14(2008), s. 39-56.

WARZECHA J., Historia dawnego Izraela, Warszawa 2005.

WARZECHA J., Samarytanie - perspektywa polityczna i religijna, w: W. CHROSTOWSKI, Słowo Twoje jest Prawdą. Księga Pamiątkowa dla Ks. Prof. Stanisława Mędali CM w 65 rocznicę urodzin, Warszawa 2000, s. 340-356.

WróBEL M.S., Księga Ezdrasza. Księga Nehemiasza. Wstęp - przekład z oryginału - komentarz - ekskursy, Tarnów 1993. 


\title{
ANTAGONIZMY JEROZOLIMSKO-SAMARYTAŃSKIE W CZASACH EZDRASZA I NEHEMIASZA
}

\author{
St r e s z c z e n i e
}

Historia Samarytan jest ściśle związana z historią Izraelitów. Od samego początku brakowało jedności między plemionami starożytnego Izraela. Po śmierci króla Salomona jego królestwo zostało podzielone na dwa odrębne państwa: Judę na południu i Izrael na północy. W 722/21 roku przed Chrystusem Królestwo Izraela upadło w wyniku inwazji asyryjskiej. Wielu mieszkańców zostało wziętych do niewoli i deportowanych do Asyrii. Na ich miejsce osiedlono ludność m.in. z Mezopotamii. To był początek społeczności samarytańskiej.

Następnym ważnym wydarzeniem, które doprowadziło do „schizmy samarytańskiej”, był upadek Królestwa Judy w 587/586 przed Chrystusem. Jego mieszkańcy zostali wzięci do trwającej niemal pięćdziesiąt lat niewoli babilońskiej. Po powrocie do Palestyny Żydzi postanowili odbudować swoją etniczną i religijną społeczność skupioną wokół Świątyni. W prace przy jej odbudowie chcieli włączyć się także Samarytanie, ale ich prośba została odrzucona. Wiele napięć powodował także fakt, że wśród różnych bogów wielbili oni także Boga Jahwe, ale nie w sposób wymagany przez Żydów z Judy. Po odrzuceniu przez Żydów Samarytanie zaczęli ustanawiać własny kult skupiony w pobliżu góry Garizim.

Słowa kluczowe: Samarytanie; Księga Ezdrasza; Księga Nehemiasza; antagonizmy jerozolimsko-samarytańskie; świątynia jerozolimska. 